\title{
UPAYA MENINGKATKAN KINERJA GURU DALAM ADMINISTRASI PEMBELAJARAN MELALUI WORKSHOP PADA SUPERVISI AKADEMIK DI MTs NEGERI BATANG
}

\author{
MINARSIH \\ Pengawas Madrasah, Kantor Kemenag Kab. Batang \\ e-mail: minarsih.batang66@gmail.com
}

\begin{abstract}
ABSTRAK
Kinerja guru merupakan sebuah proses dalam menentukan proses ketercapaian visi dan misi sekolah. Kegiatan operasional merupakan salah satu kinerja yang paling pokok di sekolah dalam pembelajaran. Hal ini tentunya memerlukan tenaga guru yang terampil dalam bidangnya atau profesional. Peneliti memilih MTs Negeri Batang sebagai obyek penelitian. Hal ini menunjukkan adanya situasi kerja yang kurang baik. Hal ini terlihat betapa penting peran kepala madrasah dalam meningkatkan kinerja guru dalam proses pembelajaran yang bermutu terutama pada administrasi. Penerapan supervisi akademik dengan teknik workshop dapat meningkatkan pembelajaran aktif dengan menyusun administrasi pembelajaran. Selanjutnya, fokus dari penelitian ini akan lebih kepada mengetahui sejauh mana kinerja guru dalam administrasi pembelajaran di MTs Negeri Batang. Penelitian ini menggunakan Penelitian Tindakan Madrasah sebagai metode. Setelah berproses dalam beberapa siklus dalam pengambilan data, peneliti menemukan guru yang menunjukkan keseriusan dalam memahami dan menyusun administrasi mengajar yang semula $79,6 \%$ apalagi setelah mendapatkan bimbingan pengembangan administrasi mengajar dari peneliti sehingga terjadinya $98,1 \%$ peningkatan ratarata dalam penyusunan administrasi mengajar sebesar 18,5\%. Hal itu juga dapat dibuktikan dari hasil observasi kualitas administrasi pembelajaranan semu memperlihatkan bahwa terjadi peningkatan kompetensi guru dari siklus 1 yang memperoleh nilai $\geq 81$ ada 4 orangdari 36 $(11,2 \%)$ ke siklus 2 yang memperoleh nilai $\geq 81$ ada 35 dari 36 guru $(97,2 \%)$ sehingga terjadinya peningkatan dalam kualitas administrasi pembelajaran sebesar $86 \%$.
\end{abstract}

Kata Kunci: Kinerja Guru, Workshop Administrasi, dan Supervisi

ABSTRACT
Teacher performance was a process in determining the achievement of the school's vision and mission. Operational activities were one of the most basic performances in schools. It required teachers' skills in their fields or professionals. The researcher chose MTs Negeri Batang as the object of research. These indicated an unfavorable working situation. These could show how important the role of madrasah principals is in improving teacher performance in the quality learning process, especially in administration. Application of academic supervision with workshop techniques can increase active learning by arranging learning administration. The focus of this research will be more to know the extent of teacher performance and also in learning administration at MTs Negeri Batang. This research uses Madrasah Action Research as a method. After proceeding in several cycles in data collection, the researchers found teachers who showed seriousness in understanding and compiling teaching administration which was origin $79.6 \%$ especially after receiving teaching administration development guidance from researchers so that there was a $98.1 \%$ increase in the average in the preparation of teaching administration by $18.5 \%$. It could be proven from the results of observations of the quality of quasi-learning administration. These showed that there was an increase in teacher competence from cycle 1 , scores 81 there are 4 people from $36(11.2 \%)$ to cycle 2 who scores 81 there are 35 of 36 teachers $(97.2 \%)$ so that there is an increase in the quality of administration learning by $86 \%$.

Keywords: Teacher Performance, Administration Workshop, and Supervision 


\section{PENDAHULUAN}

Paradigma baru memandang bahwa guru sebagai agen perubahan dalam membantu peserta didik untuk mendorong bersikap positif, membangkitkan rasa ingin tahu dan menciptakan kondisi untuk sukses dalam belajar. Hal ini menuntut kinerja guru dalam pembelajaran perlu ditingkatkan. Tugas utama guru adalah membimbing, membantu, mengarahkan peserta didik menjadi dewasa, kinerja guru menyangkut seluruh aktivitas yang ditunjukkan oleh tenaga pengajar dalam tanggungjawabnya sebagai seorang yang mengemban suatu amanat dan tanggung jawab untuk mendidik, mengajar, mengarahkan dan memandu peserta didik dalam rangka menggiring peserta didik ke arah kedewasaan mental spriritual maupun fisik biologis (Maisah, 2010). Selanjutnya, Adeyemi (2011) mengemukakan kinerja guru dapat digambarkan sebagai tugas yang dilakukan oleh seorang guru pada periode tertentu dalam sistem sekolah untuk mencapai tujuan organisasi. Hal tersebut juga didefinisikan juga sebagai tingkat pencapaian seseorang secara keseluruhan selama periode tertentu (Moeheriono, 2009). Kinerja guru merupakan sebuah tolak ukur dalam menentukan proses ketercapaian tujuan sekolah. Dengan kata lain, semakin meningkat kinerja guru saat evaluasi, maka semakin baik pula kualitas sekolah atau ornisasi tersebut.

Saat ini guru perlu menguasai administrasi pendidikan yang sesuai dengan regulasi yang ada dan memenuhi standar nasional pendidikan. Administrasi pendidikan adalah rangkaian kegiatan berencana dan sistematis yang melibatkan dan mengikutsertakan sumber-sumber potensi yang ada dan sesuai baik sarana dan prasarana maupun manusia dalam mencapai tujuan pendidikan secara lebih efektif dan efsien (Edeng, 2012). Kegiatan operasional merupakan salah satu kegiatan yang paling pokok di sekolah dalam pembelajaran. Hal ini tentunya memerlukan tenaga guru yang terampil dalam bidangnya atau profesional. Dengan guru yang profesional kegiatan administrasi pendidikan operasionalnya dapat dilakukan dalam bentuk pembelajaran. Karena tujuan administrasi pendidikan pada dasarnya adalah mengusahakan terwujudnya proses pembelajaran yang kondusif dan efektif.

Berdasarkan hasil observasi peneliti, para guru di di MTs Negeri Batang mempunyai karakter dan kinerja yang berbeda dan masih mengajar belum menyusun persiapan pembelajaran sesuai regulasi yang ada, kadang mengajar dulu sambil membuat perangkat pembelajaran termasuk menyiapkan media pembelajaran, metode yang inovatif sampai penilaian belum dibuat secara maksimal. Meskipun berbeda, mereka mempunyai tugas yang sama yaitu: (1) menyusun program pengajaran atau praktik, (2) menyajikan program pengajaran atau praktik; (3) melaksanakan evaluasi belajar atau praktek; (4) melakukan analisis hasil evaluasi belajar atau praktek; (5) menyusun dan melakukan program perbaikan dan pengayaan; (6) membimbing siswa dalam kegiatan ektrakurikuler; dan (7) membimbing guru dalam proses belajar mengajar atau praktek. Guru sebagai pelaksana langsung dalam proses belajar mengajar perlu dikelola dengan baik. Tujuan pendidikan di madrasah akan tercapai jika guru melakukan tugasnya dengan baik. Setiap guru mempunyai karakter, kemampuan, pandangan, gagasan yang berbeda-beda. Perbedaan tersebut tidak boleh menghambat dalam pelaksanaan tugas.

Berdasarkan observasi peneliti, masih ditemukan guru MTs Negeri Batang yang meninggalkan tugas mengajarnya pada jam-jam pelajaran sewaktu kepala madrasah tidak ada di madrasah. Jika kepala madrasah berada di madrasah, guru melakukan tugas seperti biasanya karena khawatir akan dinilai tidak baik. Hal ini menunjukkan adanya situasi kerja yang kurang baik. Pada kondisi lain, guru sering tidak membuat administrasi seperti rencana pengajaran, program pembelajaran, evaluasi, analisis penilaian, serta program pengayaan dan perbaikan. Akan tetapi, jika akan disupervisi oleh kepala sekolah, guru berusaha membuat administrasi mengajar sekadarnya. Jika langkah awal pembelajaran, yaitu menyusun rencana pembelajaran tidak dipersiapkan, pelaksanaan pembelajaran dapat dipastikan tidak akan berjalan dnegan baik. Proses tidak akan berjalan dengan baik. Proses pembelajaran dilakukan dengan seadanya oleh guru, media pembelajaran tidak disiapkan, dan model penilaian tidak dirancang. 
Berbagai pernyataan yang memberikan gambaran terkait sekolah MTs Negeri Batang, mulai dari kurangnya kedisplinan guru dalam pemenuhan jam mengajar dan tertib administrasi tersebut merupakan suatu kesatuan dalam penilaian kinerja guru pada penelitian ini. Peneliti mempunyai keinginan yang kuat dalam menselaraskan upaya apa saja untuk meningkatkan kinerja guru agar siap menghadapi supervisi lebih dini. Dalam meningkatkan kinerja guru salah satu strateginya adalah penguasaan guru yakni pelatihan kapasitas guru dan workshop (Harahap, 2014). Dengan adanya implementasi supervisi akademik dengan teknik workshop dapat meningkatkan pembelajaran aktif dengan menyusun administrasi pembelajaran dengan baik. Selanjutnya, tujuan dari penelitian ini akan lebih kepada mengetahui sejauh mana kinerja guru dalam administrasi pembelajaran di MTs Negeri Batang. Sehingga penulis tertarik untuk mengangkat judul sebagai berikut: "Upaya Meningkatkan Kinerja Guru dalam Administrasi Pembelajaran melalui Workshop pada Supervisi Akademik di MTs Negeri Batang"

\section{METODE PENELITIAN}

Penelitian ini dilaksanakan di MTs Negeri Batang Kabupaten Batang Provinsi Jawa Tengah pada semester gasal, waktu tiga bulan, pada bulan Juli hingga Septermber 2021. Kepala madrasah dan 36 guru mata pelajaran bertindak sebagai subjek dalam penelitian ini. Metode Penelitian Tindakan Madrasah (School Action Research) yang digunakan dalam penelitian ini adalah metode deskriptif kualitatif, dengan menggunakan teknik prosentase untuk melihat peningkatan yang terjadi dari siklus ke siklus. Teknik pengumpulan data dengan menggunakan wawancara, workshop dan observasi. Kegiatan penelitian ini menitikberatkan pada mendeskripsikan kesulitan-kesulitan yang dialami oleh guru dalam menyusun administrasi pembelajaran. Penelitian ini direncanakan dilaksanakan dalam beberapa siklus dan masingmasing siklus terdiri atas: perencanaan, pelaksanaan, observasi dan refleksi. Keempat kegiatan tersebut saling terkait dan secara urut membentuk sebuah siklus, seperti gambar berikut ini:

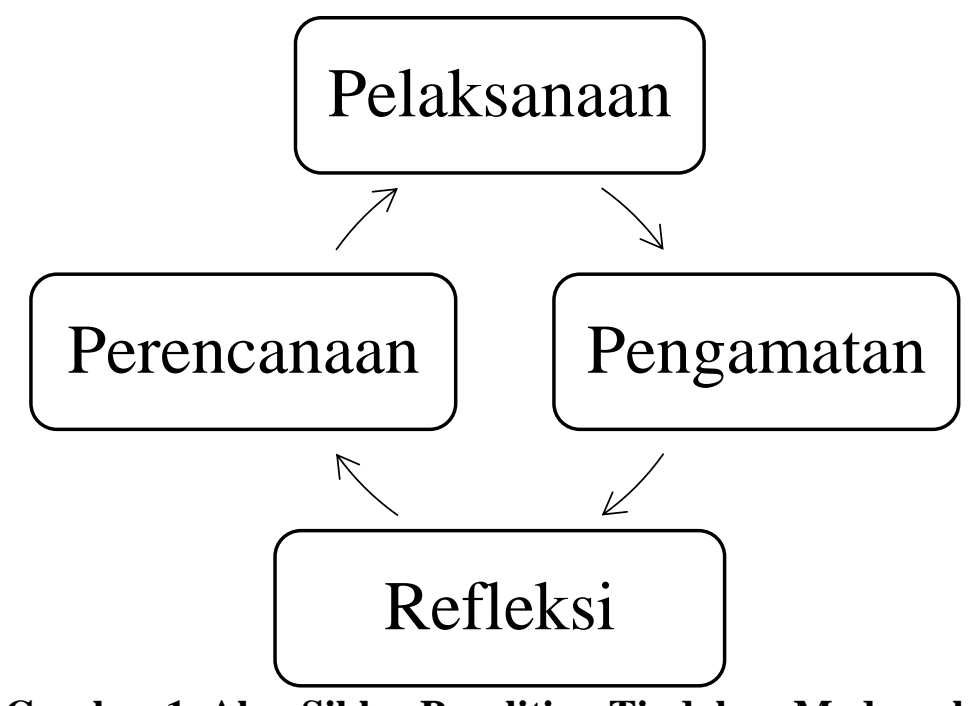

Gambar 1. Alur Siklus Penelitian Tindakan Madrasah

Secara rinci prosedur penelitian mengikuti langkah-langkah sebagai berikut: Siklus I, Tahap Perencanaan; kegiatan yang dilakukan sebagai berikut: mengadakan rapat dengan kepala dan para wakil madrasah untuk persiapan workshop, kesiapan mental dan fisik guru, persiapan bahan-bahan yang dibawa guru pada saat workshop, praktek menyusun administrasi pembelajaran; Tahap selanjutnya Pelaksanaan; 36 Guru mata pelajaran dikumpulkan untuk diadakan workshop tanggal 7 Agustus 2021 oleh pengawas madrasah. Materi workshop tentang administrasi pembelajaran yaitu Silabus, Prota, Promes, RPP Daftar Hadir dan Daftar Nilai, Kaldik, Jadwal Pembelajaran, Agenda Harian, dan KKM. Selanjutnya melakukan diskusi tentang administrasi pembelajaran dari silabus sampai dengan bentuk penilaiannya. Berikutnya Pengamatan; dilakukan penilaian dengan format khusus oleh pengawas madrasah; 
Tahap terakhir, Refleksi, Pengawas madrasah, bersama-sama kepala madrasah dan guru melakukan refleksi terhadap hal-hal yang seharunya disiapkan oleh guru ketika akan melakukan pembelajaran di kelas. Pengawas madrasah memberikan usul dan saran tentang penyusunan administrasi yang benar serta pelaksanaannya dalam proses pembelajaran.

Siklus II, dimulai Perencanaan,berdasar hasil refleksi pada siklus I, pengawas madrasah menyampaikan berbagai hal kepada guru untuk selanjutnya guru siap kembali untuk disupervisi; Tahap Pelaksanaan; Pengawas madrasah melakukan supervisi akademik dengan bekal instrumen untuk pengamatan guru; Tahap Pengamatan, dilakukan penilaian dengan format khusus oleh kepala madrasah; Tahap Refleksi, dilakukan diskusi hasil penilaian dan kemajuan-kemajuan telah dimiliki guru. Refleksi meupakan analisis dari hasil pengamatan berdasarkan data yang diperoleh. Data siklus I dan II dibandingkan untuk mengetahui keberhasilan siklus II.

\section{HASIL DAN PEMBAHASAN}

Adanya program tahunan, program semester, silabus, dan rencana pelaksanaan pembelajaran (RPP) yang dikumpulkan oleh MTs Negeri Batang merupakan syarat administrasi mengajar adalah buatan MGMP. Guru mencetak dari dokumen yang ada. Guru sering tidak melakukan perubahan atau penyesuaian dengan standar isi. Karena rencana administrasi mengajar itu bukan buatan guru sendiri sangat dimungkinkan guru tidak melakukan perubahan atau penyesuaian dengan standar isi. Bahkan dalam pembelajaran ditemukan guru yang mengajar berpegangan pada lembar kerja siswa buatan MGMP atau dari penerbit lain. Dari data yang ada, diketahui bahwa telah ada tujuh orang guru yang pernah mengikuti pendidikan dan pelatihan (Diklat) tentang kurikulum ataupun KTSP. Oleh karena itu, sebagian besar guru di MTs Negeri Batang belum sesuai standar isi, penyusunan silabus, peyusunan RPP, sampai dengan mengembangkan sistem penilaian. Di dalam RPP tergambar model pembelajaran yang akan dilakukan guru didepan kelas. Di dalam RPP juga tergambar kualitas proses kualitas proses pembelajaran yang akan dilakukan guru. Di dalam RPP juga dijelaskan aktivitas guru dan murid dalam pembelajaran. Jika RPP yang digunakan itu produk MGMP atau produk guru yang belum dapat menjabarkan standar isi dan silabus ke dalam RPP, proses pembelajaran tidak akan terlaksana dengan baik.

Selanjutnya, tujuan pembelajaran menjadi tidak sesuai dengan standar kompetensi dan kompetensi dasar seperti yang tertuang dalam standar isi. Keadaan nyata yang disebutkan di atas menunjukkan betapa penting peran kepala madrasah dalam meningkatkan kinerja guru dalam proses pembelajaran yang bermutu. Peran pengawas madrasah yang mana sebagai satusatunya MTs Negeri di Batang yang menjadi daerah binaan dan sebagai MTs induk/sebagai KKMTs sangat penting untuk dilakukan supervisi akademik dengan teknik workshop dapat meningkatkan kinerja guru. Supervisi akademik merupakan kegiatan pembinaan dengan memberi bantuan teknis kepada guru dalam melaksanakan proses pembelajaran, yang bertujuan untuk meningkatkan kemampuan profesional guru dan meningkatkan kualitas belajar mengajar, khususnya pada MTs Negeri Batang.

Ada peningkatan kemampuan guru MTs Negeri Batang dalam menyusun administrasi pembelajaran setelah mengikuti workshop. Dari Siklus I ke Siklus II dapat mencapai target minimal yang telah ditetapkan dalam menyusun administrasi pembelajaran pada masingmasing aspek. Dengan demikian dapat disimpulkan bahwa melalui worshop dapat meningkatkan kinerja guru dalam menyusun administrasi pembelajaran.

\section{A. Hasil Penelitian}

1. Deskripsi Siklus I

\section{a. Perencanaan,}

Dalam Perencanaan meliputi: (1) mengumpulkan guru melalui undangan kepala madrasah; (2) menyusun jadwal workshop: hari, tanggal, jam dan tempat; (3) menyiapkan materi workshop; pengarahan kepala madrasah, pemaparan materi Administrasi 
pembelajaran; (4) menyiapkan konsumsi untuk workshop; dan (7) menyuruh guru membawa laptop.

b. Pelaksanaan

Pada tahap ini dilakukan beberapa langkah, yakni: (1) absensi peserta; (2) pengarahan pengawas madrasah; (3) penjelasan umum kepada seluruh peserta; (4) peserta diajak mereview administrasi pembelajaran; (4) guru mengkaji langah-langkah menyusun administrasi pembelajaran; (5) guru melakukan persiapan administrasi pembelajaran; dan (6) presentasi visual dalam menyusun administrasi pembelajaran.

c. Pengamatan

Pada tahap ini dilakukan pengamatan terhadap pelaksanaan tindakan, yaitu menitikberatkan pada kompetensi guru dalam menyusun administrasi pembelajaran, sebagai akibat diterapkannya workshop. Tujuan dilaksanakan pengamatan adalah untuk mengetahui kegiatan yang mana patut dipertahankan, diperbaiki, atau dihilangkan sehingga kegitan pembinaan melalui workshop benar-benar berjalan sesuai dengan tujuan yang ada dan mampu meningkatkan kinerja peserta dalam menyusun administrasi pembelajaran.

Kegiatan peserta juga diobservasi, baik menyangkut kesiapan mental dan fisik guru, kesiapan bahan-bahan yang dibawa guru pada waktu workshop, kesiapan laptop, pengetahuan dasar tentang administrasi pembelajaran, dan kemampuan menyusun administrasi pembelajaran.

d. Refleksi

Dari hasil yang diperoleh menunjukkan bahwa guru dalam merancang administrasi pembelajaran pada siklus I belum menunjukkan hasil yang sesuai dengan indikator yang telah ditetapkan. Setelah diadakan refleksi terhadap hasil yang diperoleh, diputuskan untuk memperbaiki dari segi kegiatan workshop terutama memperjelas tentang aspek-aspek yang belum sesuai dengan indikator yang telah ditetapkan. Dari hasil tersebut tampaknya secara umum bahwa guru dalam merancang administrasi pembelajaran belum memenuhi kriteria yang ada.

Terkait dengan kesiapan guru, ditemukan bahwa guru belum menyadari bahwa pentingnya kemampuan merancang administrasi pembelajaran. Terkait dengan kesiapan laptop, guru masih banyak yang belum memiliki; alternatif solusinya adalah meminjam pada madrasah lain atau memanfaatkan komputer yang ada di madrasah. Berdasarkan hasil refleksi itu, diputuskan untuk memantapkan kegiatan pembinaan lebih memfokuskan pada aspek-aspek yang belum memenuhi indikator yang telah ditetapkan.

Dari masalah tersebut, diputuskan untuk memperbaiki beberapa langkah dalam siklus I, yakni memfokuskan pada penjelasan tentang format dan aspek penilaian dalam kaitannya dengan menyusun administrasi pembelajaran. Langkah-langkah ini dijalankan pada siklus II dengan tetap mempertahankan kegiatan yang lain yang sudah dianggap baik. Untuk meningkatkan kesiapan guru, fasilitator memberikan kesadaran bahwa betapa penting kemampuan menyusun administrasi pembelajaran sebagai kinerja yang harus dimiliki guru.

Tabel 1. Rekapitulasi Kualitas Penyusunan Administrasi Pembelajaran Siklus I

\begin{tabular}{|c|c|}
\hline Nilai & Kualitas Penyusunan dan Adm. Pembelajaran \\
\hline $91-100$ & 1 \\
\hline $81-90$ & 3 \\
\hline $71-80$ & 10 \\
\hline$\leq 70$ & 22 \\
\hline
\end{tabular}


Tabel 2. Rekapitulasi Kuantitas Penyusunan Administrasi Pembelajaran yang disusun Siklus I

\begin{tabular}{|c|c|c|}
\hline $\begin{array}{c}\text { Jenis administrasi } \\
\text { pembelajaran }\end{array}$ & Jumlah Guru & $\%$ \\
\hline Silabus & 36 & 100 \\
\hline RPP & 27 & 75 \\
\hline Prota & 28 & 78 \\
\hline Promes & 28 & 78 \\
\hline D.Hadir & 28 & 78 \\
\hline D.Nilai & 27 & 75 \\
\hline Kaldik & 28 & 78 \\
\hline Jadwal & 28 & 78 \\
\hline Agenda H & 28 & 78 \\
\hline KKM & 28 & 78 \\
\hline Rata-rata & & 79,6 \\
\hline
\end{tabular}

\section{Deskripsi Siklus 2}

Perencanaan teknis pelaksanaan kegiatan seperti: (1) mengumpulkan guru melalui undangan kepala madrasah; (2) menyusun jadwal workshop: hari, tanggal, jam dan tempat; (3) menyiapkan materi workshop; pengarahan kepala madrasah, pemaparan materi administrasi pembelajaran; (4) menyiapkan konsumsi untuk workshop; dan (5) menyuruh guru membawa laptop.

\section{a. Pelaksanaan}

Pada tahap ini dilakukan beberapa langkah, yakni: (1) absensi peserta; (2) pengarahan kepala madrasah; (3) penjelasan umum kepada seluruh peserta; (4) peserta diajak mereview administrasi pembelajaran; (5) guru mengkaji langah-langkah menyusun administrasi pembelajaran; (6) guru melakukan persiapan administrasi pembelajaran; (7) presentasi visual administrasi pembelajaran.

\section{b. Pengamatan}

Pada tahap ini dilakukan pengamatan terhadap pelaksanaan tindakan, yaitu menitikberatkan pada kompetensi guru dalam menyusun administrasi pembelajaran sebagai akibat diterapkannya workshop. Tujuan dilaksanakan pengamatan adalah untuk mengetahui kegiatan yang mana patut dipertahankan, diperbaiki, atau dihilangkan sehingga kegitan pembinaan melalui workshop benar-benar berjalan sesuai dengan tujuan yang ada dan mampu meningkatkan kinerja peserta dalam menyusun administrasi pembelajaran.

Pada siklus II ini, langkah-langkah yang diambil sesuai dengan refleksi hasil siklus I, mengikuti langlah-langkah seperti siklus I dengan memfokuskan pada penjelasan aspekaspek yang belum dipahami guru dalam menyusun administrasi pembelajaran lebih menitikberatkan pada aspek pembimbingan secara individu. Dari 30 orang guru semua dilibatkan dalam siklus II untuk memperdalam pengetahuan tentang penyusunan administrasi pembelajaran.

c. Refleksi

Dari hasil yang diperoleh menunjukkan bahwa guru dalam menyusunan administrasi pembelajaran pada siklus II sudah menunjukkan hasil yang sesuai dengan indikator yang telah ditetapkan. Setelah diadakan refleksi terhadap hasil yang diperoleh, diputuskan untuk tidak melanjutkan pada siklus berikutnya Dari hasil tersebut tampaknya secara umum bahwa guru dalam administrasi pembelajaran sudah memenuhi kriteria yang telah ditetapkan.

Terkait dengan kesiapan guru, ditemukan bahwa guru sudah menyadari betapa pentingnya kemampuan merancang administrasi pembelajaran. Terkait dengan kesiapan laptop, semua guru sudah membawa laptop. 
Tabel 3. Rekapitulasi Kualitas Penyusunan Administrasi Pembelajaran Siklus II

\begin{tabular}{|l|c|}
\hline Nilai & Kualitas Penyusunan adm pemb pembelajaran \\
\hline $91-100$ & 16 \\
\hline $81-90$ & 19 \\
\hline $71-80$ & 1 \\
\hline$\leq 70$ & 0 \\
\hline
\end{tabular}

Tabel 4.Rekapitulasi Kuantitas Penyusunan Administrasi Pembelajaran yang disusun Siklus II

\begin{tabular}{|c|c|c|}
\hline $\begin{array}{c}\text { Jenis administrasi } \\
\text { pembelajaran }\end{array}$ & Jumlah Guru & $\%$ \\
\hline Silabus & 36 & 100 \\
\hline RPP & 34 & 94 \\
\hline Prota & 36 & 100 \\
\hline Promes & 36 & 100 \\
\hline D.Hadir & 36 & 100 \\
\hline D.Nilai & 35 & 97 \\
\hline Kaldik & 34 & 94 \\
\hline Jadwal & 36 & 100 \\
\hline Agenda H & 34 & 94 \\
\hline KKM & 35 & 97 \\
\hline Rata-rata & & 97 \\
\hline
\end{tabular}

3. Perkembangan Siklus 1 dan 2

Tabel 5. Rekapitulasi Kualitas Penyusunan Administrasi Pembelajaran Siklus 1 dan 2

\begin{tabular}{|c|c|c|c|c|}
\hline \multirow{2}{*}{ Nilai } & \multicolumn{4}{|c|}{ Kualitas Penyusunan adm pembelajaran } \\
\cline { 2 - 5 } & Siklus 1 & $\%$ & Siklus 2 & $\%$ \\
\hline $91-100$ & 1 & 2,8 & 1 & 53.2 \\
\hline $81-90$ & 3 & $8 ; 4$ & 1 & 44 \\
\hline $71-80$ & 10 & 27.8 & 1 & 2.8 \\
\hline$\leq 70$ & 22 & 61 & 0 & 0 \\
\hline & & & & \\
\hline
\end{tabular}

Tabel 6.Rekapitulasi Kuantitas Penyusunan Administrasi Pembelajaran yang disusun Siklus 1 dan 2

\begin{tabular}{|c|c|c|c|c|}
\hline \multirow{2}{*}{$\begin{array}{c}\text { Jenis } \\
\text { Administrasi }\end{array}$} & \multicolumn{4}{|c|}{ Jumlah Guru } \\
\cline { 2 - 5 } & Siklus 1 & $\%$ & Siklus 2 & $\%$ \\
\hline Silabus & 36 & 100 & 36 & 100 \\
\hline RPP & 27 & 75 & 34 & 95 \\
\hline Prota & 28 & 78 & 36 & 100 \\
\hline Promes & 28 & 78 & 36 & 100 \\
\hline D.Hadir & 28 & 78 & 36 & 100 \\
\hline D.Nilai & 27 & 75 & 35 & 98 \\
\hline
\end{tabular}




\begin{tabular}{|c|c|c|c|c|}
\hline Kaldik & 28 & 78 & 34 & 95 \\
\hline Jadwal & 28 & 78 & 36 & 100 \\
\hline Agenda H & 28 & 78 & 34 & 95 \\
\hline KKM & 28 & 78 & 35 & 98 \\
\hline & & 79,6 & & 98,1 \\
\hline
\end{tabular}

Setelah perbaikan penyusunan administrasi pembelajaran pada siklus 2 selesai, peneliti dan pengamat melakukan diskusi tentang pelaksanaan perbaikan. Berdasarkan diskusi tersebut peneliti dan pengamat merumuskan beberapa bahan refleksi. Hasil analisis perbaikan penyusunan administrasi pembelajaran pada siklus1 tingkat ketercapaian lebih dari sama dengan 81 ada $4(11,2 \%)$ guru dari 36 guru.Sedangkan pada siklus 2 menunjukkan bahwa kualitas penyusunan administrasi pembelajaran yang tuntas dengan tingkat ketercapaian lebih dari sama dengan 81 ada 35 guru $(97,2, \%)$ guru dari jumlah 36 berarti dengan kenaikan $86 \%$, berarti sudah di atas kriteria ketuntasan klasikal yaitu $81 \%$.

Selain itu hasil analisis perbaikan Kuantitas guru yang telah melaksanakan penyusunan administrasi pembelajaran pada siklus 1 rata-rata 79,6 dari 10 administrasi pembelajaran yang disusun 36 guru. Pada siklus 2 menunjukkan kemajuan yang signifikan ada 35 guru (98\%) guru dari jumlah 36 berarti, berarti sudah di atas kriteria ketuntasan klasikal yaitu $81 \%$. Sehingga pada perbaikan Siklus II dikatakan berhasil, maka perbaikan administrasi pembelajaran tidak perlu diulang lagi.

\section{B. Pembahasan Hasil Penelitian}

Berdasarkan analisis dan pembahasan seperti yang telah dipaparkan pada bagian sebelumnya, maka disimpulkan bahwa terjadi peningkatan kinerja guru dalam administrasi pembelajaran melalui workshop pada supervisi akademik di MTs Negeri Batang ada tiga pulu enam (36) guru dan dilaksanakan dalam siklus 1 dan siklus 2. Semua guru tersebut menunjukkan sikap yang baik dan termotivasi dalam menyusun administrasi mengajar dengan lengkap. Hal ini peneliti ketahui dari hasil pengamatan pada saat melakukan wawancara dan bimbingan penyusunan administrasi mengajar.

Selanjutnya dilihat dari kompetensi guru dalam menyusun administrasi mengajar, terjadi peningkatan dari siklus 1 ke siklus 2 .

1. Silabus; dari ke-37 (100\%) guru yang telah membuat silabus hasilnya cukup baik, tidak ada satu pun guru yang tidak membuat silabus, $100 \%$.

2. Rencana Pelaksanaan Pembelajaran (RPP); Adanya peningkatan pembuatan RPP yakni pada siklus 1 ada 27 (75\%) guru yang membuat RPP, pada siklus 2 yang membuat RPP 35 (95\%) guru setelah berdialog dengan peneliti, dengan kata lain terjadi peningkatan sebesar $20 \%$.

3. Program Tahunan (Prota); Adanya peningkatan pembuatan Prota yakni pada siklus 1 ada $28(78 \%)$ guru yang membuat Prota, pada siklus 2 yang membuat Prota $36(100 \%)$ guru setelah berdialog dengan peneliti, dengan kata lain terjadi peningkatan sebesar $22 \%$.

4. Program Semester (Prosem); Adanya peningkatan pembuatan Promes yakni pada siklus 1 ada $28(78 \%)$ guru yang membuat Promes, pada siklus 2 yang membuat Promes 36 (100\%) guru setelah berdialog dengan peneliti, dengan kata lain terjadi peningkatan sebesar $22 \%$.

5. Daftar Hadir (DH); Adanya peningkatan pembuatan Daftar Hadir yakni pada siklus 1 ada $28(78 \%)$ guru yang membuat Daftar Hadir, pada siklus 2 yang membuat Daftar Hadir $36(100 \%)$ guru setelah berdialog dengan peneliti, dengan kata lain terjadi peningkatan sebesar $22 \%$.

6. Daftar Nilai (DN); Adanya peningkatan pembuatan Daftar Nilai yakni pada siklus 1 ada $27(75 \%)$ guru yang membuat daftar nilai, pada siklus 2 yang membuat Daftar 
Nilai 35 (98\%) guru setelah berdialog dengan peneliti, dengan kata lain terjadi peningkatan sebesar 23\%.

7. Kalender Pendidikan; Adanya peningkatan pembuatan kaldik yakni pada siklus 1 ada $28(78 \%)$ guru yang membuat kalender pendidikan, pada siklus 2 yang membuat kaldik 34 (95\%) uru setelah berdialog dengan peneliti, dengan kata lain terjadi peningkatan sebesar $23 \%$.

8. Jadwal Pelajaran; Adanya peningkatan pembuatan Jadwal Pelajaran yakni pada siklus 1 ada 28 (78\%) guru yan membua Jadwal Pelajaran, pada siklus 2 yang membuatJadwal Pelajaran $36(100 \%)$ guru setelah berdialog dengan peneliti, dengan kata lain terjadi peningkatan sebesar $22 \%$.

9. Agenda Harian; Adanya peningkatan pembuatan agenda Harian yakni pada siklus 1 ada $28(78 \%)$ guru yang membuat agenda harian, pada siklus 2 yang membuat agenda Harian $34(95 \%)$ guru setelah berdialog dengan peneliti, atau terjadi peningkatan sebesar $17 \%$.

10. KKM; Adanya peningkatan pembuatan KKM yakni pada siklus 1 ada 28 (78\%) guru yang membuat KKM, pada siklus 2 yang membuat KKM 35 (98\%) guru setelah berdialog dengan peneliti, dengan kata lain terjadi peningkatan sebesar $20 \%$.

\section{KESIMPULAN}

Penelitian ini dapat disimpulkan sebagai berikut, dengan dilaksanakannya workshop dapat meningkatkan motivasi guru dalam menyusun administrasi mengajar dengan lengkap dan perencanaan mengajar melalui supervisi akademik sehingga menghasilkan pembelajaran yang lebih bermutu. Guru menunjukkan keseriusan dalam memahami dan menyusun administrasi mengajar yang semula 79,6\% apalagi setelah mendapatkan bimbingan pengembangan administrasi mengajar dari peneliti sehingga terjadinya $98,1 \%$ peningkatan rata-rata dalam penyusunan administrasi mengajar sebesar $18,5 \%$.

Kegiatan workshop dengan supervisi akademik dapat meningkatkan kompetensi guru dalam menyiapkan perencanaan pembelajaran yang pada akhirnya meningkatkan mutu pembelajaran. Hal itu dapat dibuktikan dari hasil observasi kualitas administrasi pembelajaranan semua memperlihatkan bahwa terjadi peningkatan kompetensi guru dari siklus 1 yang memperoleh nilai $\geq 81$ ada 4 orang dari $36(11,2 \%)$ ke siklus 2 yang memperoleh nilai $\geq 81$ ada 35 dari 36 guru $(97,2 \%)$ sehingga terjadi peningkatan dalam kualitas administrasi pembelajaran sebesar $86 \%$.

\section{DAFTAR PUSTAKA}

Abadi. (2007). Pengaruh Hasil Pendidikan dan Pelatihan Kepemimpinan Kepala Sekolah terhadap Kinerja Guru di SMP Negeri se-Kota Surakarta. Semarang: Mimbar Pendidikan LPMP Jawa Tengah

Anwar. (2004). Manajemen Kepemimpinan Kepala Sekolah. Bandung: Program Pascasarjana UPI Bandung

Arikunto. (2006). Administrasi Pendidikan untuk Kejuruan. Jakarta: Rineka Cipta.

Atmodiwirio. (2007). Kinerja Kepala Sekolah dan Upaya Meningkatkannya. Bandung : Rosdakarya.

Hariwung. (2004). Supervisi Pendidikan. Jakarta : Dirjendikti P2LPTK.

Iskandar, U. (2013). Kepemimpinan kepala sekolah dalam peningkatan kinerja guru. Jurnal visi ilmu pendidikan, Vol. 10 (1) from http://dx.doi.org/10.26418/jvip.v10i1.2061

Jatmiko. (2008). Pengaruh Kompensasi dan Budaya Sekolah terhadap Kinerja Guru di SMP

Negeri 1 Semarang. Semarang : Mimbar Pendidikan LPMP Jawa Tengah

Martinis Yamin, Maisah. (2010). Standarisasi Kinerja Guru. Jakarta: GP Press.

Nawawi. (2004). Administrasi dan Supervisi Pendidikan. Bandung: Aneka Ilmu.

Nurgiantoro. (2002). Manajemen Kinerja Pegawai. Jakarta: Ghalia Indonesia.

Rivai. (2004). Administrasi dan Manajemen Pendidikan. Bandung: Jemmars. 
Sujana. (2009). Standar Mutu Pengawas. Jakarta: Depdiknas.

Suryana, E. (2012). Administrasi Pendidikan dalam Pembelajaran. CV. Budi Utama.

Susanto, A. (2016). Manajemen Peningkatan Kinerja Guru Konsep, Strategi, dan Implementasinya from https://play.google.com/store/books/details?id=Gh2eDwAAQBAJ\&source=gbs_api

Undang-Undang No 14 Tahun 2005. Tentang Guru dan Dosen. Jakarta: Balai Pustaka

Wahjosumidjo. (2002). Kepemimpinan Kepala Sekolah (Tinjauan Teoritis dan Permasalahannya). Jakarta: PT Raja Grafindo Persada. 